\title{
Public Sector Accounting and Organizational Performance: A Study in the Indonesian Health Care Industry
}

\author{
Inggriani Elim ${ }^{\mathrm{a}, *}$, Aneke Wangkar ${ }^{\mathrm{a}}$, Treesje Runtu ${ }^{\mathrm{a}}$, Lady D. Latjandu ${ }^{\mathrm{a}}$ \\ ${ }^{a}$ Accounting Dept, Faculty of Economics and Business, University of Sam Ratulangi, Manado, Indonesia
}

\begin{abstract}
The implementation of public sector accounting is a crucial factor in improving the performance of public sector organizations. One of the organizations that implement public sector accounting is the health care industry. The purpose of this study is to analyze public sector accounting's effect on organizational performance in the health care industry. This research is quantitative research conducted at a health institution in Manado City. Respondents who participated included 100 participants from regional hospitals and health centers in Manado City, Indonesia. Data analysis is assisted by path analysis. The research findings reveal the relationship of public sector accounting to the performance of public sector organizations and the relationship mediated by accounting information systems. Several limitations and suggestions were revealed in this study.
\end{abstract}

Keywords: public sector accounting, organizational performance, accounting information system, health care industry

\section{INTRODUCTION}

Reform of public sector organizations, especially in the health care sector, is a process that must continue to be carried out regardless of various policies and political and organizational changes that overshadow the organization's health care (Organization, 2000). The need for reform is because health systems are very complex things that adapt according to empirical, demographic, and societal shifts (Figueroa et al., 2019). Even managing health organizations in the new public management era is a "Sisyphean challenge" (Newman and Lawler, 2009), which is a task that is pointless, fruitless, and unrewarding (University of Oxford, 2011). However, the impact of the COVID19 pandemic has changed the order of the health care industry to become one of the most critical industries for humanity in the 21 st century, overshadowing the health and even lives of individuals living on earth (Blumenthal et al., 2020).

Public sector accounting is one of the essential aspects of organizational management and new public management (NPM), which directly impacts the performance of public organizations (Macinati and Pessina, 2014). Public sector accounting in the health care industry is also an essential part of garnering revenue and reducing unnecessary costs for the management of

*Author in correspondence,

Email address: inggriani_elim@unsrat.ac.id (Inggriani Elim) public organizations Seetharaman et al. (2010) that are more effective, efficient, accountable, and transparent. The implementation of public sector accounting is often different in organizations in the health care industry, especially health institutions such as hospitals and clinics whose ownership and management are public organizations such as governments and foundations.

Public sector accounting as part of NPM continues to develop and is implemented rapidly throughout the world (Robinson, 2015) in both developed and developing countries (Kusnawati et al., 2018). This theory continues to be developed in various fields ranging from public asset accounting management (Elim et al., 2019) to accounting information systems management (Macinati and Pessina, 2014). The development of this theory impacts the development of theories in the field of public sector accounting to improve the performance of public sector organizations.

Several studies have been conducted related to the study of the relationship between public sector accounting and the performance of public organizations. Research from Italy on the relationship between accounting and financial performance in public sector health organizations (Macinati and Pessina, 2014) was conducted on the leaders and managers of public sector organizations in Italy, as many as 265 respondents. Using structural equation modeling (SEM) analysis, it is found that public sector accounting plays a significant role in improving financial performance. This study mainly investigates the relationship between public sector accounting and the performance of public sector organizations. Many studies related to the relation- 
ship between public sector accounting and performance (Macinati and Pessina, 2014), but a mediated relationship with accounting information systems have not been found (Alim and Siswantoro, 2019).

This research's main objective is to analyze how the relationship between public sector accounting and the performance of public organizations is mediated by accounting information systems. This research was conducted in Eastern Indonesia (Kawung et al., 2018), namely in Manado City, located in the northernmost province directly adjacent to the Philippines.

\section{LITERATURE REVIEW}

\subsection{New Public Management}

New public management (NPM) is a person's effort to responsibly run an organization and utilize resources to achieve the goals of an organization that focuses on the welfare of community entities (Shafritz et al., 2017). The concept of NPM is a management activity that is applied to the public sector and related matters such as (Hope, 2001): implementation of private management practices in the public sector, focusing on efficiency, changing from input controls, rules, and procedures to output measurement and performance targets, and devolution of management with improved reporting and monitoring.

NPM aims to foster a performance-oriented cultural ecosystem with decentralized public sector management. Some of its characteristics include: (1) a closer focus on results in terms of service quality, efficiency, and effectiveness; (2) a hierarchical structure in the form of a decentralized management environment; (3) flexibility to explore alternatives to direct public provision and regulation; (4) focus on efficiency in the service provided directly by the public sector; (5) strengthening of strategies that can respond to external changes and diversity of interests automatically, flexible, and low-cost (Hope, 2001).

\subsection{Public Sector Accounting}

Public sector accounting is an accounting system that includes recording and accounting management by government authorities to achieve financial performance (Abhishek N. and Divyashree, 2019). From an economic point of view, the public sector can be understood as an entity whose activities are related to efforts to produce public goods and services to fulfill public needs and rights. Public sector accounting is defined as an accounting technique and analysis mechanism applied to the management of public funds in high state institutions and lower departments, local governments, state-owned enterprises, regionally-owned enterprises, NGOs, and social foundations, as well as sector collaboration projects, public and private (Jones and Pendlebury, 2010).

The objectives of public sector accounting include (Glynn, 2003): (1) providing the necessary information to manage appropriately, efficiently, and economically the allocation of resources entrusted to the organization. This objective is related to management control; and (2) provide information that enables managers to report on the proper and effective implementation of program responsibilities and use of resources under their authority and enables government employees to report publicly on the results of government operations and the use of public funds. This goal is related to accountability.

Public sector accounting in Indonesia refers to government regulation number 71 of 2010, namely, Government Accounting Standards (Pemerintah Republik Indonesia, 2010). This regulation regulates government accounting in Indonesia, referring to article 1 paragraph 3 , defined as accounting principles applied in preparing and presenting government financial statements.

\subsection{Public Sector Performance}

Measurement or assessment of public sector performance is a series of processes for recording and measuring the achievement of the implementation of activities in achieving the mission accomplishment through the results displayed in products, services, and processes (Helden and Reichard, 2013). To find out the goods or services produced from the activities carried out and the policies of the activities that reflect the functioning of the outputs in a program, it is necessary to conduct a performance assessment in both the private and public sectors (Presidential Regulation about Government Institution Performance Accountability System, 2014).

The purpose of measuring the performance of public organizations is to communicate better strategies, balance financial and non-financial performance measurements, accommodate an understanding of management's vision from top to bottom, achieve satisfaction, and assess the rational ability of the organization's individuals (Goh, 2012). The types of information used to measure the performance of the public sector are (1) financial information; and (2) non-financial information (Helden and Reichard, 2013).

\subsection{Accounting Information System}

The public sector accounting information system (PSAIS) is a power-sharing system within local government organizations by processing financial data, ranging from accounting records to presenting information in financial statements the design of an integrated information processing system to manage ac-counting information systems. In addition, the design of vari-ous elements of internal control is embedded in the information processing system (Bastian, 2007). The public sector account-ing information system was developed due to changes in the political, social, and economic systems brought about by the current reforms that gave rise to various demands for good gov-ernment governance. Indonesian Government Regulation No. 58 (2005) (Government Regulation about Regional Financial Management) requires the need for accountability in financial reports by regional heads so that regional financial managers are needed to allocate resources efficiently and effectively. The public sector accounting system is an accurate elaboration tool for good government governance.

The concept of the Regional Government Accounting System in Indonesia refers to the Government Accounting System as stated in Article 1 paragraph (11) of the Government Regulation on Government Accounting Standard No. 71 (2010), which states that the Government Accounting System is a systematic series of procedures, organizers, equipment, and other 
elements to realize the accounting function from transaction analysis to financial reporting within government organizations. Therefore, the Regional Government Accounting System is a systematic series of procedures, administration, equipment, and other elements to realize the accounting function from transaction analysis to financial reporting within local government organizations.

\section{RESEARCH METHODS}

This type of research uses quantitative research. Quantitative data are generally collected through questions and surveys (Apuke, 2017). The study was conducted at health institutions in Manado City with a sample of employees in public sector health institutions. Sampling used quota sampling until the specified sample was reached, which obtained 100 participants in this study. The variables used include public sector accounting, contemporary accounting practices $\left(X_{1}\right)$, traditional accounting practices $\left(X_{2}\right)$, accounting information systems $(Z)$, and the performance of public organizations. The indicators of these variables are taken from the research of (Nuhu et al., 2016) for variables $X_{1}$ and $X_{2}$; (Alim and Siswantoro, 2019) for indicators of variable $Z$, and (Lee, 2008) and (Northcott and Tulapapa, 2012) for variable Y. The analysis used is path analysis, which is a model that describes the effect of one set of variables on other variables. Path analysis aims to estimate causal relationships that are represented by path diagrams (Stage et al., 2004).

\section{RESULT AND DISCUSSION}

Participants in this study were dominated by women (79\%), aged between $31-40$ years (35\%), with the latest education being a bachelor's (S1) or an applied degree (D4) (41\%). The workplace organization is a hospital (50\%). Working as administrative staff or health workers (54\%), the length of work is between 5-10 years (32\%).

Table 1: Sociodemographic Characteristics Summary

\begin{tabular}{lll}
\hline \multirow{2}{*}{ Variable } & \multicolumn{2}{l}{ Coefficient } \\
\cline { 2 - 3 } & CA & Description \\
\hline $\begin{array}{l}\text { Contemporary Account- } \\
\text { ing Practice (CAP) (X1) }\end{array}$ & 0.902 & Reliabel \\
$\begin{array}{l}\text { Traditional Accounting } \\
\text { Practice (TAP) (X2) }\end{array}$ & 0.948 & Reliabel \\
$\begin{array}{l}\text { Accounting Information } \\
\text { System (AIS) (Z) }\end{array}$ & 0.889 & Reliabel \\
$\begin{array}{l}\text { Public Organization Per- } \\
\text { formance (POP) (Y) }\end{array}$ & 0.871 & Reliabel \\
\hline
\end{tabular}

Source:Author's elaboration

The variable public sector accounting: current accounting practices (CAP) has a substantial link with the accounting information system (AIS), according to the hypothesis testing results . The considerable value of CAP to AIS, which is positive

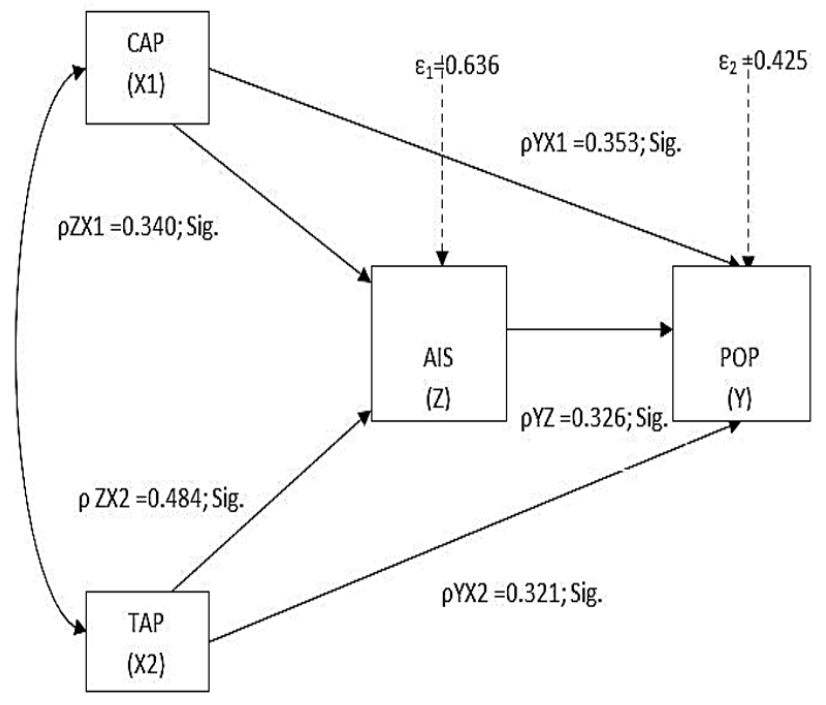

Figure 1: Path Analysis Result

Table 2: The Results of Impacts of Path Analysis Relation

\begin{tabular}{lcccc}
\hline \multirow{2}{*}{ Relation } & \multicolumn{3}{l}{ Impact } & \multicolumn{3}{l}{ Path } & Direct & Indirect & Total \\
& Coeff & & & \\
\hline CAP to AIS & 0.340 & 0.340 & - & 0.340 \\
TAP to AIS & 0.484 & 0.484 & - & 0.484 \\
CAP to POP & 0.353 & 0.353 & $0.340 \times 0.326$ & 0.463 \\
& & & $=0.110$ & \\
TAP to POP & 0.321 & 0.321 & $0.484 \times 0.326$ & 0.478 \\
& & & $=0.157$ & \\
AIS to POP & 0.326 & 0.326 & - & 0.326 \\
$\epsilon_{1}$ & 0.636 & 0.636 & - & 0.636 \\
$\epsilon_{2}$ & 0.425 & 0.425 & - & 0.425 \\
\hline
\end{tabular}

Source:author's elaboration, 2021

and significant, demonstrates this link. Then there's the direct impact of CAP, which has a big impact on AIS.

The variable public sector accounting: conventional accounting procedures (TAP) has a substantial association with the AIS, according to the hypothesis testing results. The considerable value of TAP to AIS, which is positive and significant, demonstrates this outcome. Then there's the immediate consequence of TAP having a strong connection to AIS.

According to hypothesis testing, the variable public sector accounting: current accounting practices (CAP) has a substantial association with public organizational performance (POP), which is mediated by the AIS. According to hypothesis testing, the variable public sector accounting: TAP has a strong link with POP, which is mediated by the AIS. The AIS variable has a substantial influence on the POP, according to the findings of hypothesis testing.

This research backs up prior studies, such as Agustiawan's (2019) study on public organizations, which revealed that im- 
plementing public sector accounting has a substantial impact on public organization performance. The tools and indicators employed, the analytical tool, SEM-PLS, and the location and purpose of study at the Yogyakarta local government are the distinctions. This research adds to prior research on the link between public sector accounting and accounting information systems in government agencies (Apridiyanti, 2020).

A path analysis tool is used to determine the similarity. The key distinction between this study and prior research is the indicators employed, as well as the fact that the research was conducted in West Java, Indonesia. This research adds to prior work by Alim and Siswantoro (2019), who discovered a link between accounting information systems and the efficiency of public-sector performance. The indicators employed in this study, as well as the analysis method, path analysis, are the key components of the equation. The distinction in this comparison is the research object, which is the municipal government of Depok City in West Java, Indonesia.

\section{CONCLUSION}

This study is likely to add to accounting research and practices in the public sector. The contributions of this study indicate certain discoveries in terms of public sector accounting. To begin, modern accounting practice in public sector organizations has a direct, indirect, and overall influence on public organizational performance in Manado's public sector health care business, which is mediated through the accounting information system. Second, conventional accounting procedures in the public sector have a direct, indirect, and overall impact on public performance, which is mediated through the accounting information system.

As a result, two research questions have been boldly and clearly addressed. Furthermore, the implementation of public sector accounting in the context of public sector performance in the Manado health care business was demonstrated in this study.

\section{References}

Abhishek N., Divyashree, M. S., 2019. Public Sector Accounting System-A Conceptual Analysis. Vision. Journal of Indian Taxation 6 (2), 26-36. URL: https://doi.org/10.17492/vision.v6i2.186480

Alim, D. L., Siswantoro, D., 2019. The Effect of the Accounting Information System (AIS) on Accounting and Financial Task Efficiency at the Depok City Local Government Finance Office 39.

URL: https://doi .org/10.2991/apbec-18.2019.57

Apuke, O. D., 2017. Quantitative Research Methods A Synopsis Approach. Arabian Journal of Business and Management Review (Kuwait Chapter) 6 (10), 40-47.

URL: https://doi .org/10.12816/0040336

Bastian, I., 2007. Public Sektor Accounting System. Salemba Empat.

Blumenthal, D., Fowler, E. J., Abrams, M., Collins, S. R., 2020. Covid19-Implications for the Health Care System. The New England Journal of Medicine 383 (17), 1483-1488.

URL: https ://doi.org/10.1056/nejmsb2021088

Elim, I., Runtu, T., Wangkar, A., 2019. Analysis of Regional Property Management in Public Organization in Indonesia (Study at the Regional Financial and Asset Management Agency of Talaud Islands Regency). Advances in Economics, Business and Management Research 127 (1), 201-205.

URL: https://doi.org/10.2991/aebmr.k. 200309.044
Figueroa, C. A., Harrison, R., Chauhan, A., Meyer, L., 2019. Priorities and challenges for healthleadership and workforce managementglobally: A rapid review. BMC Health Services Research 19 (239), 239.

URL: https://doi .org/10.1186/s12913-019-4080-7

Glynn, J. J., 2003. Public Sector Financial Control and Accounting. Blackwell Publisher.

URL: https://www amazon . com/Public-Sector-Financial-Con trol-Accounting/dp/0631188622

Goh, S. C., 2012. Making performance measurement systems more effective in public sector organizations. Measuring Business Excellence 16 (1), 31-42. URL: https://doi.org/10.1108/13683041211204653

Helden, G. J. V., Reichard, C., 2013. A meta-review of public sector performance management research. Tékhne - Review of Applied Management Studies 11 (1), 10-20.

URL: https://doi.org/10.1016/j.tekhne.2013.03.001

Hope, K. R., 2001. The new public management: Context and practice in Africa. International Public Management Journal 4 (2), 119-134. URL: https://doi .org/10.1016/S1096-7494(01)00053-8

Jones, R., Pendlebury, M., 2010. Public Sector Accounting (6 ed.). Pearson Education.

URL: https://www. pearson.com/uk/educators/ higher-education-educators/program/

Jones-Public-Sector-Accounting-6th-Edition/PGM986164. html

Kawung, G. M. V., Mintardjo, C. M. O., Rompas, W. I., Kojo, C., 2018. Kemudahan Memulai, dan Melembagakan Bisnis UKM di Kawasan Timur Indonesia (KTI) (Kajian pada Kabupaten/Kota di Sulawesi Utara). Unsrat Press.

Kusnawati, E. F., Amartur, K., Armanu, Hadiwidjodjo, D., 2018. Effectiveness of Asset Management in the Public Sector with the Application of Asset Management, Accountability, Monitoring and Evaluation, and Quality of Human Resources (Case Study in Government of Blitar City-East Java). Journal of Applied Management (JAM) 17 (4), 567-575.

URL: https ://doi.org/10.21776/ub.jam.2019.017.04.01

Lee, N., 2008. Developing and validating an instrument to assess performance of public sector organisations: A case study of Malaysian schools. Measuring Business Excellence 2 (3), 56-75.

URL: https://doi.org/10.1108/13683040810900403

Macinati, M. S., Pessina, E. A., jul 2014. Management accounting use and financial performance in public health-care organisations: Evidence from the Italian National Health Service. Health Policy 117 (1), 98-111. URL: https://doi.org/10.1016/j.healthpol.2014.03.011

Newman, S., Lawler, J., 2009. Managing health care under New Public Management: A Sisyphean challenge for nursing. Journal of Sociology 45 (4), 419-432.

URL: https ://doi.org/10.1177/1440783309346477

Northcott, D., Tulapapa, T. M., 2012. Using the balanced scorecard tomanage performance in publicsector organizationsIssues and challenges. International Journal of Public Sector Management 25 (3), 166-191. URL: https ://doi.org/10.1108/09513551211224234

Nuhu, N. A., Baird, K., Appuhami, R., 2016. The Association between the Use of Management Accounting Practices with Organizational Change and Organizational Performance. Advances in Management Accounting 26 (1), 67-98.

URL: https ://doi.org/10.1108/S1474-787120150000026003

Organization, W. H., 2000. Health Sector Reform: Issues and Opportunieties (Report No. 18/4; 18th Meeting of Ministers of Health).

URL: https://apps . who.int/iris/handle/10665/127574

Pemerintah Republik Indonesia, 2010. Peraturan Pemerintah (PP) Nomor 71 Tahun 2010 tentang Standar Akuntansi Pemerintahan.

URL: https://peraturan.bpk.go.id/Home/Details/5095/ pp-no-71-tahun-2010

Robinson, M., 2015. From Old Public Administration to the New Public Service: Implications for Public Sector Reform in Developing Countries. UNDP for Global Centre for Public Service.

Seetharaman, A., Raj, J. R., Saravanan, A. S., 2010. The Changing Role of Accounting in the Health Care Industry. Research Journal of Business Management 4 (2), 91-102.

URL: https://doi.org/10.3923/rjbm.2010.91.102

Shafritz, J. M., Russell, E. W., Borick, C. P., Hyde, A. C., 2017. Introducing Public Administration. Routledge. 
Stage, F. K., Carter, H. C., Nora, A., 2004. Path Analysis: An Introduction and Analysis of a Decade of Research. The Journal of Educational Research 98 (1), 5-13.

URL: https://doi.org/10.3200/JOER.98.1.5-13
University of Oxford, 2011. Concise Oxford English Dictionary: Main edition (12 ed.). Oxford University Press. 